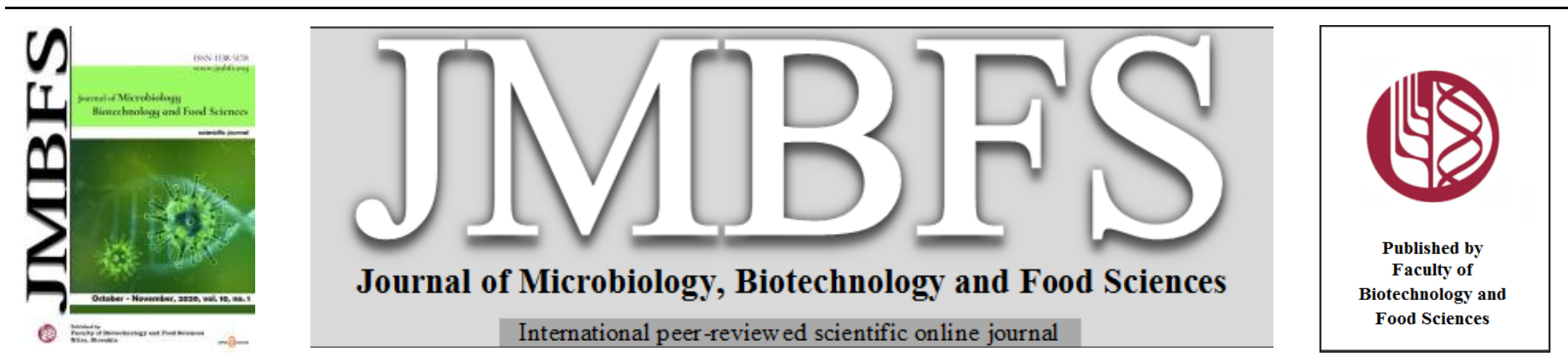

\title{
THE EXPRESSION OF SELECTED DROUGHT RESPONSIVE GENES OF MAIZE IS INFLUENCED BY ENDOPHYTIC BACTERIAL INOCULATION
}

\author{
Shrey Bodhankar ${ }^{l}$, Minakshi Grover ${ }^{1,2 *}$, Manjunath mallappa ${ }^{1}$, Gopal Reddy ${ }^{3}$, Daipayan Ghosh ${ }^{4}$, Sridev Mohapatra ${ }^{4}$
}

Address(es):

${ }^{1}$ ICAR- Central Research Institute for Dryland Agriculture, Hyderabad-500 059, Telangana, India.

${ }^{2}$ Division of Microbiology, ICAR- Indian Agricultural Research Institute, New Delhi-110 012, India.

${ }^{3}$ Department of Microbiology, Osmania University, Hyderabad-500 007, Telangana, India.

${ }^{4}$ Department of Biological Sciences, Birla Institute of Technology and Science (Pilani), Hyderabad Campus-500 078, Telangana, India.

*Corresponding author: minigt3@yahoo.co.in

doi: $10.15414 / j m b f s .2020 .10 .2 .267-272$

\section{ARTICLE INFO}

Received 1. 6. 2019

Revised 18. 6. 2020

Accepted 29. 6. 2020

Published 1. 10. 2020

Regular article

open ${ }_{\text {ACCESS }}$

\begin{abstract}
Plants respond to abiotic stresses through a series of molecular, cellular and physiological changes. These responses are further influenced by the interactions between host plant and the associated rhizospheric and endophytic microorganisms. The endophytic microorganisms, due to their intimate proximity with the host plant, are considered to have major influence on plant's physiological responses. In the present study, three drought tolerant and plant growth promoting maize seed endophytic bacteria, Bacillus sp. MSEB 17, Bacillus sp. MSEB 72 and Bacillus sp. MSEB 78 were used as seed inoculants in maize (var Bioseed 9681) under drought stress conditions in a growth chamber pot study and their influence on four drought responsive genes (Zmdhn1, GRMZM2G055844, GRMZM2G467339 and GRMZM2G109448) in maize leaves was studied by real time PCR using specific primers. The influence of inoculation on host plant's response to drought was evident from altered expression of target genes when compared with uninoculated plants. Notably, inoculation with MSEB 17 increased the expression of three target genes, Zmdhnl (dehydrin) gene, GRMZM2G467339 gene and GRMZM2G109448 gene by several folds. This study revealed the role of endophytic in alleviating the effect of drought stress in maize plants through regulating plant growth and physiological response.
\end{abstract}

Keywords: Bacillus; Dehydrin; abiotic stress; RT-PCT

\section{INTRODUCTION}

Drought is severely affecting the agricultural production (Li et al. 2015). It is predicted that, by the end of 2050, more than half of arable lands will face water crisis. Climate change would further worsen this in the coming days threatening food security (Lobell et al. 2011; Mancosu et al. 2015). In India, nearly 50\% of the cropped area is considered as severely drought prone (Kamble et al., 2010). Further, climate change induced severity of drought events is likely to threaten the agricultural productivity and food security of the country in near future. Therefore, drought readiness is particularly important for monsoon based agroeconomy of India (Ghosh $\boldsymbol{e t}$ al., 2019). Hence, efforts are needed in the direction of developing suitable technologies to enhance drought tolerance/resistance of the crop plants.

Maize (Zea mays L.), an important cereal crop, contributes significantly towards food, livestock and biofuel production. In India, maize is the third most important food crops after rice and wheat playing a major role in the country's food security. As the crop is majorly grown in rainfed areas, pattern of rainfall influences plant growth and yield by influencing soil moisture availability (Byjesh et al., 2010). Drought is reported to be the major factor that affects maize yield (around 15\% loss) in rainfed areas (Edmeades, 2008). Any strategies to combat drought stress in maize will be highly advantageous in these areas. In this direction, use of microbial resources may provide safe and sustainable solutions.

Role of microorganisms in shaping host's health and fitness is becoming more and more evident from accumulating reports on plant-microbiome and humanmicrobiome interactions. The microorganisms which colonize internal tissues of the plants without causing any disease are referred as endophytes. Similar to rhizosphere microorganisms, endophytes have been reported to play an important role in plant growth and development (Hardoim et al., 2008; Gagné-Bourque et al., 2016). However, the localization of endophytes inside the host provides extra advantage in terms of nutrient availability and shelter against external unfavorable conditions. Generally, some of the rhizosphereic and phyllospheric bacteria eventually infect the plant, colonize the internal tissue become endophytic. Some of these endophytes find their route towards seeds and establish their as seed endophytes that may be transmitted vertically to the daughter plant after germination (Okungbowa et al., 2019). Plants secrete chemo-attractants through root exudates, which facilitating plant-microbe cross talk thus influencing endophytic colonization (Kawasaki et al., 2016). Due to their intimate relationship with the host plant, the endophyte can be explored as suitable candidates for development of bioinoculants. Besides plant growth promotion, endophytes have been reported to confer protection to the host plant from biotic and abiotic stresses (Bodhankar et al., 2017; Bodhankar et al., 2019; Coutinho et al., 2015). However, the intricacies of host-endophyte interactions are yet to be unraveled.

Plant-microbe interactions involve complex mechanisms within the plant cellular system. Physiological, biochemical and molecular studies help to understand these complex and integrated cellular processes. To understand plant-microbe relationships in improving plant tolerance to abiotic stresses, it is essential to gain deeper insights into the stress-mitigating mechanisms of crop plants. Different omics approaches viz., genomics, transcriptomics, proteomics, metabolomics and phenomics are being used to understand interaction of plants with microbes and their external environment (Meena et al., 2017). Several genes have been found responsible for conferring drought stress tolerance in plants (Joshi $\boldsymbol{e t}$ al., 2016). In order to reveal complex genetic mechanisms of drought tolerance, the diversity of stress response genes and their contribution to plant needs to be investigated. It can be facilitated by analysis of gene expression at transcriptomic, proteomic and metabolomic levels. Comparison of transcriptome profiles is helpful in identifying different sets of transcripts responsible for differences between two biologically different expressions in varying conditions (Bräutigam and Gowik, 2010). Transcriptomic analyses have been used to discover stress responsive genes (Shinozaki and Yamaguchi-Shinozaki, 2007; Hayano-Kanashiro et al., 2009). The real-time PCR (RT-PCR) is a modern and efficient tool in measuring the levels of mRNA expression in any biological samples. The differential gene expression under varying conditions can help in understanding the response of biological system to a particular condition. Drought tolerance is considered as quantitative trait, involving the participation of a complex set of genes. Stress 
tolerant genotypes/species are thought to be expressing novel stress responsive genes with unique functional significance (Waditee $\boldsymbol{e t}$ al., 2002). Researchers have reported that the inoculation with plant beneficial endophytic bacteria can influence the expression of drought responsive genes (Gagné-Bourque $\boldsymbol{e t}$ al. 2016). However, majority of such studies have used Arabidopsis as model plant (Timmusk and Wagner 1999). Here, we report the influence of seed endophytic bacteria, able to alleviate drought stress effects in maize plants when preinoculated through seed bacterization at the time of sowing, on drought responsive genes in maize plants. The objective of the present investigation was to study the effect of inoculation of bacterial endophytes on plant growth biochemical and expression of selected drought responsive genes in drought stressed maize plants.

\section{MATERIAL AND METHODS}

\section{Maize seed endophytic bacteria}

Selected potential maize seed endophytic bacteria (MSEB-17, MSEB 72 and MSEB 78) used in the present study, were previously isolated from surface sterilized seeds of 3 different genotypes of maize (Z59-17, PSRJ-13041 and Z3287) (Bodhankar et al., 2017). The isolates could exhibit plant growth promoting traits and improved plant growth under drought stress conditions (Bodhankar $\boldsymbol{e}$ al., 2019). On the basis of 16SrRNA sequence analysis, the isolates MSEB-17, MSEB 72 and MSEB 78 exhibited highest similarity to Bacillus licheniformis Bacillus subtilis and Bacillus subtilis in the NCBI GenBank database. The sequences have been submitted to NCBI under the accession numbers KU877804, KU877809 and KU877806, respectively. These cultures have also been deposited at National Agriculturally Important Microbial Culture Collection (NAIMCC), India under the accession numbers NAIMCC-B-01938, NAIMCC B-01936, NAIMCC-B-01937, respectively. The bacterial cultures were maintained on nutrient agar (NA) slants at $4{ }^{\circ} \mathrm{C}$ and multiplied as and when required using the same medium.

\section{Growth chamber experiment}

The plant growth chamber experiment was conducted with five treatments. The treatments T1 (MSEB-17), T2 (MSEB-72), T3 (MSEB-78), T4 (un-inoculated) were subjected to drought stress whereas T5 (un-inoculated) was irrigated. Maize seeds (cv. Bioseed 9681) were surface sterilized as per the procedure described in Bodhankar et al. (2017). The surface sterilized seeds were soaked in freshly raised bacterial broth $\left(\sim 10^{8}\right.$ cells $\left.\mathrm{ml}^{-1}\right)$ for one hour and immediately sown in plastic pots filled with sterile soil $(2.5 \mathrm{Kg} / \mathrm{pot})$. The soil for the pot experiment was Alfisol collected from $0-15 \mathrm{~cm}$ depth from research farm of CRIDA, Hyderabad, India (a semi-arid region under rainfed production system). The soil contained $72 \%$ sand, $9 \%$ silt, and $19 \%$ clay with $36 \%$ water holding capacity and $1.42 \mathrm{Mg} \mathrm{m}^{-3}$ bulk density and electrical conductivity of $0.103 \mathrm{~ms}$. Organic C, available $\mathrm{N}$ and $\mathrm{P}$ and $\mathrm{K}$ contents of soil were $0.4 \%, 210 \mathrm{~kg} / \mathrm{ha}, 28 \mathrm{~kg} / \mathrm{ha}$ and 150 $\mathrm{kg} / \mathrm{ha}$ respectively. The soil was sterilized by autoclaving twice for $20 \mathrm{~min}$ a $120^{\circ} \mathrm{C}$ with a $24 \mathrm{~h}$ interval. The pots were kept in environmental growth chambe (JSR-JSGC-960C-F, JS Research Inc, Republic of Korea) and the following conditions viz., temperature $28 / 25^{\circ} \mathrm{C}$ (day/night), relative humidity $(70 \%)$ and photoperiod (12h) were maintained (Fig. 1).

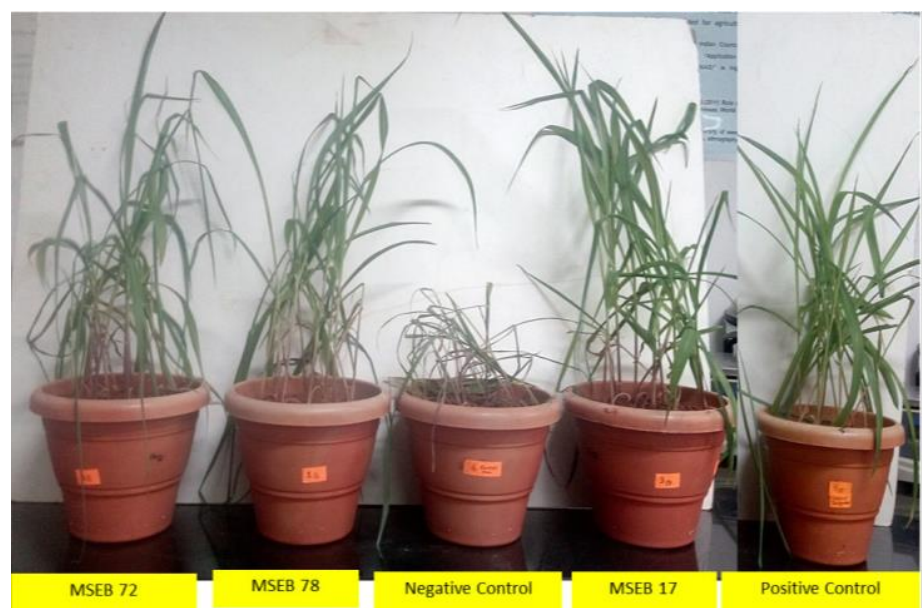

Figure 1 Growth chamber experiment of maize seedlings inoculated with MSEB

All the plants were watered once in two days with sterile water to field capacity upto 21 days after sowing. Thereafter, watering was stopped in all the treatments, (except in T5), to impose drought conditions. The seedlings were observed closely for the appearance of stress symptoms (rolling and wilting of leaves). After 7 days of withholding water, the observations on expression of drough responsive genes, total chlorophyll (measured by Minolta SPAD chlorophyll meter-502), were recorded and the plants were harvested to measure plant growth (shoot length, shoot fresh and dry weight) and biochemical parameters (proline, total sugar content) and soil moisture content. The dry biomass of shoot samples was recorded after oven drying at $70^{\circ} \mathrm{C}$ till constant weight.

\section{Estimation of proline, total sugar and soil moisture content}

Free proline accumulation in leaves was estimated as per the procedure described by Bates et al. (1973). Briefly, fresh leaf sample (500 $\mathrm{mg}$ ) was homogenized with $5 \mathrm{ml}$ of aqueous sulfosalicylic acid (3\%) in a mortar and pestle. The volume of the extract was made up to $10 \mathrm{ml}$ with aqueous sulfosalicylic acid. Two $\mathrm{ml}$ of acid ninhydrin and $2 \mathrm{ml}$ of glacial acetic acid were added to the $2 \mathrm{ml}$ of extract The mixture was incubated for $1 \mathrm{~h}$ at $100^{\circ} \mathrm{C}$ in boiling water-bath and then, transferred to an ice-bath to terminate the reaction. Four $\mathrm{ml}$ of toluene was added and mixed vigorously using a vortex mixer for 15 to 20 seconds. The absorbance of the chromophore was measured at $520 \mathrm{~nm}$ in a spectrophotometer (Thermo Spectronic 336009, USA) against an appropriate blank. The proline content was determined from the standard curve prepared with proline and expressed as $\mu \mathrm{mol} / \mathrm{g}$.

Total sugar content in leaves was estimated by phenol-sulphuric acid method (Dubois et al., 1956). Briefly, fresh leaf sample (500 $\mathrm{mg})$ was extracted twice with $5 \mathrm{ml}$ of ethanol $(80 \%)$. To $0.5 \mathrm{ml}$ of the extract, one $\mathrm{ml}$ of $5 \%$ phenol and 5 $\mathrm{ml}$ conc. sulphuric acid were added followed by incubation for $20 \mathrm{~min}$ at room temperature for the development of stable yellow orange color. The absorbance was read at $490 \mathrm{~nm}$ using spectrophotometer (Thermo Spectronic, USA). The concentration of total sugars was calculated from the standard curve prepared using glucose. Soil moisture content was estimated by gravimetric method (Jalota et al., 1998).

\section{Real time PCR for gene expression studies}

\section{RNA isolation}

Total RNA was isolated from maize leaves $(0.5 \mathrm{~g})$ using Trizol® reagent (Invitrogen, Carlsbad, CA) (Ghosh et al., 2017). The RNA was electrophoresed and visualized on $1.2 \%(\mathrm{w} / \mathrm{v})$ agarose gel (Sambrook $\boldsymbol{e t}$ al., 1989). The RNA was quantified by Nanodrop ${ }^{\circledR}$ ND-1000 spectrophotometer. The RNA samples with $260 / 280$ ratio between 1.9 and 2.0 and $260 / 230$ ratio on or above 2.0 were used for RT-PCR analysis.

\section{cDNA synthesis and qPCR}

The cDNA synthesis from total RNA $(1 \mu \mathrm{g})$ was done using Superscript III Reverse Transcriptase (Invitrogen). Semi-quantitative PCR was performed using respective primers (Xu et al., 2014) of the following genes - Zmabp3, Zmdhn1, GRMZM2G055844, GRMZM2G467339 and GRMZM2G109448 (Table 1). Zmabp3 was used as reference gene for data normalization. The data obtained was corroborated using real-time quantitative PCR (Step One Plus, Applied Biosystems, USA) using SYBR green PCR master mix. Gene expression analysis was done as relative quantification by following the $\Delta \Delta \mathrm{CT}$ method (Livak and Schmittgen, 2001). Statistical analysis was done to compare data between two different treatments by student's t-test (two-tailed analysis, $\mathrm{p} \leq 0.05$ ).

\section{Statistical analysis}

Comparisons between treatments were carried out by two-way analysis of variance (ANOVA) using SPSS software package version 19 (IBM SPSS Statistics 19, USA). Each treatment was analyzed with three replicates and a standard deviation (SD) was calculated and data are expressed in mean $\pm \mathrm{SD}$.

\section{RESULTS}

Effect of inoculation of MSEB on plant growth parameters and soil moisture content under drought stress condition

The treatments which included bacterial endophytes viz., improved shoot length $(29.7-41.9 \%)$, shoot fresh weight $(14.1 \%-36.4 \%)$, shoot dry weight $(21.4 \%$ $50 \%)$ and chlorophyll content $(12.2-19.8 \%)$ in comparison with uninoculated drought stressed control. Highest shoot length was observed in the treatment with MSEB 72, followed by MSEB 78 and MSEB 17 with $41.9 \%, 37.4 \%$ and $29.7 \%$ increase respectively over uninoculated drought stressed control treatment (Table 1). Maximum improvement in shoot fresh weight was observed in the treatment with MSEB 17 (36.4\%) followed by MSEB 78 (34.4\%) and MSEB 72 $(14.1 \%)$ over uninoculated drought stressed control. Similar trend was also observed in case of shoot dry weight treatment with MSEB 17 showing maximum improvement over control $(50 \%)$ followed by MSEB $78(28.5 \%)$ and MSEB $72(21.4 \%)$. Similarly, highest chlorophyll content was recorded in MSEB 17 (19.8\% increase over control) followed by MSEB 72 (13.1\% increase over control) and MSEB 78 (12.2\% increase over control) in comparison with the control (Table 1). Among MSEB treatments MSEB 72 showed higher soil moisture content (16.9\%) followed by MSEB 17 and MSEB $78(6.2 \%)$ under 
drought stress condition as compared to un-inoculated control treatment (Table $1)$.

Table 1 Inoculation effects of selected MSEB isolates on maize growth, physiological and soil moisture content parameters under drought condition in sterile soil

\begin{tabular}{lccccccc}
\hline Treatments & $\begin{array}{c}\text { Chlorophyll } \\
\text { (SPAD units) }\end{array}$ & $\begin{array}{c}\text { Shoot length } \\
(\mathbf{c m})\end{array}$ & $\begin{array}{c}\text { Shoot fresh } \\
\text { weight }(\mathbf{g})\end{array}$ & $\begin{array}{c}\text { Shoot dry } \\
\text { weight }(\mathbf{g})\end{array}$ & $\begin{array}{c}\text { Proline } \\
(\mu \text { mol/g fresh } \\
\text { weight })\end{array}$ & $\begin{array}{c}\text { Sugar (mg/g fresh } \\
\text { weight) }\end{array}$ & $\begin{array}{c}\text { Soil moisture } \\
\text { Content }(\%)\end{array}$ \\
\hline T1 (MSEB 17) & $39.2 \mathrm{a}( \pm 0.7)$ & $50.89 \mathrm{~b}( \pm 0.44)$ & $2.02 \mathrm{a}( \pm 0.004)$ & $0.21 \mathrm{a}( \pm 0.003)$ & $0.84 \mathrm{a}( \pm 0.005)$ & $6.72 \mathrm{a}( \pm 0.53)$ & $1.7 \mathrm{c}(0.18)$ \\
T2 (MSEB 72) & $37 \mathrm{~b}( \pm 0.4)$ & $55.64 \mathrm{a}( \pm 0.93)$ & $1.69 \mathrm{c}( \pm 0.003)$ & $0.17 \mathrm{c}( \pm 0.002)$ & $0.64 \mathrm{~b}( \pm 0.003)$ & $5.06 \mathrm{~cd}( \pm 0.005)$ & $1.87 \mathrm{~b}(0.08)$ \\
T3 (MSEB 78) & $36.7 \mathrm{~b}( \pm 0.1)$ & $53.89 \mathrm{ab}( \pm 0.18)$ & $1.99 \mathrm{~b}( \pm 0.002)$ & $0.18 \mathrm{~b}( \pm 0.002)$ & $0.61 \mathrm{c}( \pm 0.002)$ & $5.39 \mathrm{~b}( \pm 0.186)$ & $1.7 \mathrm{~cd}(0.13)$ \\
T4 (Negative control) & $32.7 \mathrm{c}( \pm 0.1)$ & $39.21 \mathrm{c}( \pm 1.23)$ & $1.48 \mathrm{~d}( \pm 0.002)$ & $0.14 \mathrm{~d}( \pm 0.001)$ & $0.49 \mathrm{~d}( \pm 0.003)$ & $4.96 \mathrm{~d}( \pm 0.031)$ & $1.6 \mathrm{~d}(0.12)$ \\
T5 (Positive control) & $35 \mathrm{~b}( \pm 0.2)$ & $49.2 \mathrm{~b}( \pm 0.55)$ & $1.60 \mathrm{c}( \pm 0.003)$ & $0.16 \mathrm{c}( \pm 0.002)$ & $0.53 \mathrm{~d}( \pm 0.001)$ & $5.09 \mathrm{~cd}( \pm 0.005)$ & $11.7 \mathrm{a}(0.26)$ \\
\hline CV \% & 1.64 & 2.67 & 0.28 & 2.19 & 0.81 & 6.8 & 8.3 \\
LSD & 1.41 & 2.51 & 0.008 & 0.004 & 0.01 & 0.82 & 0.5 \\
\hline
\end{tabular}

When compared with uninoculated irrigated control, the drought stressed inoculated plants exhibited improved shoot length $(3.4 \%-13 \%)$, shoot fresh weight $(5.6 \%-26.2 \%)$, shoot dry weight $(6.2 \%-31.2 \%)$ and chlorophyll content $(4.8 \%-12 \%)$. Highest increase in shoot length was observed in the treatment with MSEB 72 (13\%), followed by MSEB 78 (9.5\%) and MSEB 17 (3.4\%) over the uninoculated irrigated control treatment (Table 1). Maximum increase in shoot fresh weight was observed in the treatment with MSEB $17(26.2 \%)$ followed by MSEB $78(24.3 \%)$ and MSEB $72(5.6 \%)$. Similar trend was also observed in case of shoot dry weight treatment with MSEB $17(31.2 \%)$ showing maximum increase, followed by MSEB $78(12.5 \%)$ and MSEB $72(6.25 \%)$ Maximum increase in chlorophyll content was recorded in MSEB $17(12 \%)$ followed by MSEB $72(5.7 \%)$ and MSEB $78(4.8 \%)$ in comparison with the control (Table 1).

Effect of inoculation of MSEB isolates on plant physiological parameters under drought stress

Inoculation with endophytic bacteria improved the proline and sugar content in plants as compared to uninoculated control under drought stress conditions. Maximum proline content was observed in the treatment with MSEB $17(71.4 \%)$ followed by MSEB $72(30.6 \%)$ and MSEB 78 (24.4\%) in comparison with uninoculated control. Similarly, highest sugar concentration was recorded in the treatment with MSEB 17 (35.4\%) followed by MSEB 78 (8.6\%) and MSEB 72 $(2 \%)$ as compared with un-inoculated control (Table 1)

When compared with uninoculated irrigated control plants, the drought stressed inoculated plants exhibited higher proline and sugar content. Maximum increase in proline content was observed in the treatment with MSEB $17(58.4 \%)$ followed by MSEB $72(20.7 \%)$ and MSEB 78 (15\%) in comparison with uninoculated control. Similarly, highest increase in sugar concentration was recorded in the treatment with MSEB 17 (32\%) followed by MSEB $78(5.8 \%)$ as compared with un-inoculated control (Table 1).

\section{Real time PCR analysis for expression of drought responsive genes in maize}

Real time PCR was carried out to understand the expression of stress responsive genes in maize plants inoculated with endophytic bacteria. Four candidate drought responsive genes Zmdhn1, GRMZM2G055844, GRMZM2G467339 and GRMZM2G109448 (Table 2) were selected for present study and corresponding primer pairs were designed. Gene Zmabp3, translating into an actin binding protein was used as endogenous control for relative quantification of the expression of the target genes. The expression profile in the host under drought stress varied among the treatments in the present study. Zmdhnl is a stres responsive gene belonging to dehydrin family. Dehydrins bind to various molecules such as water, phospholipids thus indicating protective activity. Although, the molecular functions of the dehydrins are still not understood a positive relationship between the level of accumulation of dehydrin transcripts and plant stress tolerance has been reported in several physiological studies focusing on plant stress response (Choura and Brini, 2018). In the present study drought stressed maize plants treated with MSEB 72, MSEB 78 and MSEB 17 showed increase in the expression of Zmdhnl gene (dehydrin) by $40.3 \%, 33.5 \%$ and $30.5 \%$ respectively (Fig. 2).

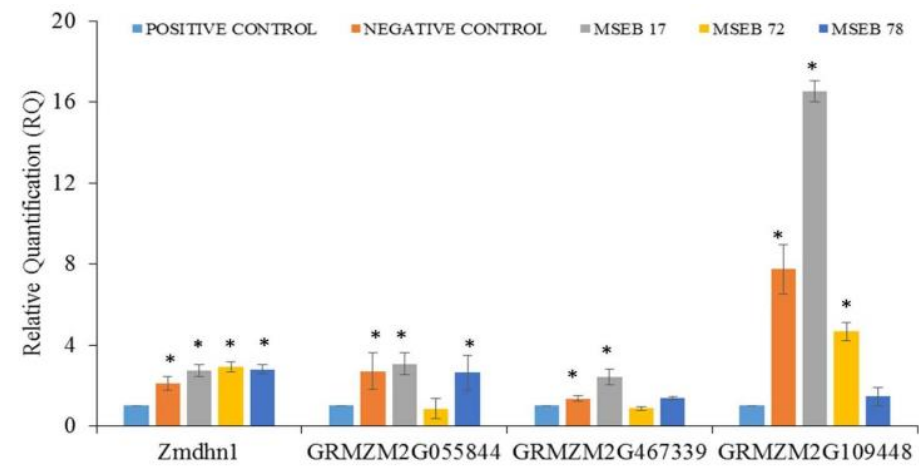

Figure 2 Expression profile of drought responsive genes in maize as influenced by maize seed endophytic bacteria under drought stressed condition. Each bar represents mean \pm SE. "**” indicates significant difference $(p \leq 0.05)$ in data between positive control and any other treatment of analysis. Statistical analysis was done to compare ciata betwcen two different treatments by student's t-test (two-tailed analysis, $\mathrm{p} \leq 1.05$ ).

Inoculation with MSEB $\mathrm{i} /$ increased the expression of all the three target genes, Zmdhn1 (dehydrin) gene, GRMZM2G467339 gene and GRMZM2G109448 gene by several folds in the drought stressed maize plants. However, the expression of gene GRMZM2G109448 that increased significantly under MSEB 17 treatment exhibited significant reduction under MSEB 72 and MSEB 78 treatments.

\section{DISCUSSION}

\section{Effect of maize seed endophytes on maize plant growth parameters}

Drought is one of the major limitations to food production worldwide and is estimated to have reduced national cereal production by $9-10 \%$ (Xu et al., 2014) There is a need to find environmentally friendly solutions to increase tolerance to drought stress and allow growth of plants under water limited condition (Xu $\boldsymbol{e t}$ al., 2014). Three Bacillus spp. strains (MSEB 17, MSEB 72, MSEB 78) used in the present study were previously isolated as seed endophytes from different maize genotypes. The three MSEB strains possess multiple plant growth promoting traits like indole acetic acid production, siderophore production, antagonism against fungal pathogens and lytic enzymes production. Besides, the strains exhibited tolerance to salinity $(10 \% \mathrm{NaCl})$, osmotic stress $(40 \%$ PEG6000), and high temperature $\left(60^{\circ} \mathrm{C}\right)$ (Bodhankar et al., 2017; Bodhankar et al., 2019). Isolation of the bacterial strains from dried seed environment indicated their ability to sustain under unfavorable conditions. Expression of multiple plant growth promoting traits, tolerance to abiotic stresses and production of lytic enzymes make them suitable candidates to be deployed as bioinoculants under stress conditions. Further, successful endophytic colonization by these strains in the roots, shoots and leaves of maize plants has been reported using rifampicin resistance marker (Bodhankar et al., 2017). Bacteria belonging to genus Bacillus and possessing multiple plant growth promoting traits have been reported to enhance drought tolerance in different crops (Vardharajula $\boldsymbol{e}$ al., 2011; Kavamura et al., 2013, Grover et al., 2014, Santana et al., 2020). In the present study, MSEB inoculated treatments (MSEB 17, MSEB 72 and MSEB 78) showed better plant growth parameters, chlorophyll, shoot length, shoot fresh biomass, shoot dry biomass and physiological parameters, proline and sugar content, soil moisture content indicating the positive effect of inoculation on plant growth under drought stress and well watered conditions. Most damaging effect of drought stress is associated with photosynthetic process of plant. Many studies have shown that decrease in photosynthetic activity under drought stress can be attributed to non-stomatal and stomatal limitations (Zlatev and Yordanov, 2004). Bleaching of leaves exposed directly to the sun under drought stress can be observed (Sheikh et al., 2017). However, inoculation with stress 
tolerant PGPR have been found to reduce the effects of drought on chlorophyll content. High chlorophyll content has been connected with drought tolerance in maize (Zaeifizade and Goliov, 2009). According to Grover et al. (2014) chlorophyll content in the inoculated treatments (Bacillus spp. strains) was higher as compared to respective control treatments in both the sets indicating better physiological health of inoculated plants under stress conditions. In this study, MSEB inoculations improved chlorophyll content under drought stress as compared with un-inoculated control (Table 1). Grover et al. (2014) reported positive effect of bacterial inoculation on shoot length and biomass as compared to uninoculated control treatments. Similarly, Timmusk et al. (2014) showed that under drought stress, wheat plants treated with PGPR had $78 \%$ higher biomass than non-treated plants, confirming the potential of PGPR to enhance plant performance under drought stress. In present study MSEB inoculation improved shoot length which resulted in better survival, shoot biomass compared to the uninoculated control (Table 1).

Effect of maize seed endophytes on plant physiological parameters and soil moisture content

Plants are known to accumulate organic osmolytes under drought stress, such as proline and sugars that contribute to the tolerance of host plant under drought through enhanced osmoregulation (Trotel-Aziz et al., 2000). Proline is synthesized in response to extensive range of abiotic stresses and is an essentia metabolite that mediates osmotic adjustment, stabilizes sub-cellular structures, and scavenges free radicals (Hare and Cress, 1997). Accumulation of sugars in different parts of plants is enhanced in response to the variety of environmental stresses (Prado et al., 2000). Estimation of proline and sugars at regular intervals after exposure to stress can give better understanding about the effect of microbial inoculation on biochemical parameters (Grover et al., 2014). In terms of proline and sugars, Positive effect of MSEB inoculation MSEB was observed However, treatment with MSEB 17 recorded higher proline and sugar content, as compared un-inoculated treatment (Table 1). Soil texture is the only facto affecting the moisture content at permanent wilting. The soil moisture content at the time of permanent wilting might conceivably be affected by the plant species, environmental conditions and the soil texture (Naveed $\boldsymbol{e t}$ al., 2014). Grover $\boldsymbol{e}$ al., 2014 reported treatment with KB129 inoculation exhibited significantly high soil moisture content. In this study, positive influence of MSEB inoculation was observed on soil moisture content, may be related to biofilm formation and production of exopolysaccharide by inoculated endophytes which help in moisture conservation in the rhizosphere and on the root surface. Inoculation with MSEB 72 showed higher soil moisture content followed by MSEB 17 and MSEB 78 inoculated treatments.
RT PCR based expression of drought responsive genes in maize as influenced by MSEB inoculation

Various stress conditions cause altered gene expression in the biological systems. Understanding the functions of the stress responsive genes can help to unravel the possible mechanisms of stress tolerance in a biological system. According to Ghosh et al., (2017) a drought tolerant Pseudomonas putida GAP45 resulted in several fold increase in the expression of proline biosynthesis genes in drough stressed Arabidopsis thaliana and the altered expression could be positively correlated with morpho-physiological evidences of water-stress mitigation in the plants. Gupta et al. (2010) reported that the recombinant $E$ coli cells harboring $S b D R E B 2 A$ (dehydration-responsive element binding transcription factor) from a halophyte, exhibited better growth under stress conditions indicating the role of this transcription factor in regulation of stress related functional genes. Gene expression analysis by Gond $\boldsymbol{e t}$ al. (2015) revealed that inoculation with $P$. agglomerans caused upregulation of the aquaporin genes in maize plants under salt stress conditions.

Zmdhnl (dehydrin) is a stress responsive gene. The role of dehydrins, however, could be part of defence mechanisms against pathogen infection, usually present during periods of water scarcity. In the present study seed inoculation with all the three isolates enhanced the expression of Zmdhn1 in drought stressed maize plants with MSEB 72 exhibiting maximum increase in expression of ZmdhnI gene (2-fold). Evidence exists of an induction by wounding, which is a common stress due to insect attack, but which is also considered a dehydration stress, as the cellular damage can lead to water loss (Hanin et al., 2011). Inoculation with endophytic Trichoderma harzianum mitigated abiotic stress in rice by upregulating aquaporin, dehydrin, and malonialdehyde genes (Pandey et al., 2016).

The gene GRMZM2G055844 has been related with protein kinase activity. Protein kinases are important components in the signal transduction pathways of various environmental signals in plants. Expression of several plant protein kinase genes has been shown to be induced by water deficit conditions. Protein reversible phosphorylation is catalyzed by protein kinases and phosphatases and also is one of the most ubiquitous and important regulatory pathways of signal transduction and physiological metabolism in plants (Hong et al., 1997; Li et al. 2009). In present study treatment with MSEB 17 showed increased expression of GRMZM2G055844 gene by $13 \%$ compared with uninoculated control under drought stress (Table 2 and Fig. 2).

\begin{tabular}{|c|c|c|}
\hline Genes & Target genes & Primer sequences \\
\hline G1. & $\begin{array}{l}\text { Zmabp3 - actin binding protein } \\
Z \text {. mays encoding the actin binding protein, the } 18 \mathrm{~S} \text { small } \\
\text { subunit of ribosomal RNA ( } \mathrm{Zm} 18 \mathrm{SRNA})\end{array}$ & $\begin{array}{l}\text { Forward: } \\
\text { TGTGAACGATGAGTGCATGCT } \\
\text { Reverse: } \\
\text { CGGTGCAGCCTCTTCGA }\end{array}$ \\
\hline $\mathrm{G} 2$. & Zmdhn1 - Dehydrin as stress responsive gene & $\begin{array}{l}\text { Forward: } \\
\text { AGGAAGAAGGGAATCAAGGAGAAGA } \\
\text { Reverse: } \\
\text { CGTGCTGGTCGTCCTTGT }\end{array}$ \\
\hline G3. & GRMZM2G055844 - Protein kinase activity & $\begin{array}{l}\text { Forward: } \\
\text { TATGTCCAGTCAGCGAGAG } \\
\text { Reverse: } \\
\text { GGCTATGTCCACGATCATTG }\end{array}$ \\
\hline G4. & GRMZM2G467339 - Sorghum bicolor hypothetical protein & $\begin{array}{l}\text { Forward: } \\
\text { GTATGTCTTAATAGGTATGTCTCA } \\
\text { Reverse: } \\
\text { GTACACCCGATGTTCTTC }\end{array}$ \\
\hline G5. & GRMZM2G109448 - Histone H2A Protein Zea mays & $\begin{array}{l}\text { Forward: } \\
\text { GCTGTCTCATCCTCATCG } \\
\text { Reverse: } \\
\text { CCAATCTGTGAAGAAGTGAAG }\end{array}$ \\
\hline
\end{tabular}

The GRMZM2G467339 is a Sorghum bicolor hypothetical protein and has been related to drought response (Xu et al., 2014). Treatment with MSEB 17 exhibited higher expression by $78.4 \%$ followed by MSEB 78 that showed $2.7 \%$ increase in the expression of GRMZM2G467339 as compared with control treatment under drought stress condition (Table 2 and Fig. 2). The GRMZM2G109448 is a histone $\mathrm{H} 2 \mathrm{~A}$ protein (Zea mays). A basic core histone octamer for nucleosomes is composed of histones $\mathrm{H} 2 \mathrm{~A}, \mathrm{H} 2 \mathrm{~B}, \mathrm{H} 3$, and $\mathrm{H} 4$. Histone variants, such as $\mathrm{H} 2 \mathrm{~A}$ function in precise and specific regulation of gene activity and genome structure. $\mathrm{H} 2 \mathrm{~A}$ deposition plays an important role in thermal stress responses. It has been reported to be up-regulated under water stress conditions (Yu et al., 2003) Treatment with MSEB 17 resulted in highest expression of GRMZM2G109448 gene by $113.3 \%$ compared to uninoculated control under drought stress condition (Table 2 and Fig. 2). We noted that the treatment with MSEB 72 down-regulated GRMZM2G055844 and GRMZM2G467339 genes and MSEB 78 down-regulated
GRMZM2G109448 gene in leaves. This might indicate different levels of interaction between host plant and various microbial strains. Down regulation of stress responsive gene also indicate homeostatic effect of the inoculated strains In a study by Fukami et al. (2018) maize plants inoculated with Azospirillum brasilense strains alone or in combination with Rhizobium tropici responded positively under saline conditions, however the response varied with the microbial strains. They observed that heat-shock protein $h s p 70$ were downregulated in leaves and roots, indicating that inoculation with PGPB might reduce the need for this protection. However, more studies are needed to understand the variation among different strains in influencing the stress response of host plant The present study reveals the role of endophytic bacteria in influencing the drought response of maize plant as indicated by altered expression of selected stress responsive genes in the inoculated treatments oven control. Further, the 
response of the host plant towards stress conditions varies with the inoculant strains, indicating the need to scrutinize the strains at molecular levels.

\section{CONCLUSION}

These efficient maize seed endophytic bacterial strains improved the plant growth and physiological parameters under drought condition. These strains can be further evaluated under field conditions and the potential strain/s may be developed as bioinoculant for important rain-fed crops. Inoculation with MSEB 17 increased the expression of Zmdhn1 (dehydrin) gene, GRMZM2G467339 gene and GRMZM2G109448 gene by several folds. These genes have been associated with drought response in maize plant, indicating that bacterial endophytes influence the response of host plant to drought conditions at genetic levels. This study can form the basis to understand the molecular host-endophyte interactions and population dynamics under stress conditions and advantages of using endophytes over rhizobacteria.

Acknowledgments: Authors of this manuscript are thankful to ICAR-AMAAS (Application of Microorganisms in Agriculture and Allied Sectors) for the financial support and ICAR- Central Research Institute for Dryland Agriculture, Hyderabad for providing necessary facilities.

Conflict of interest statement: The authors have declared no conflict of interest.

\section{REFERENCES}

Bates, LS., Waldren, RD., Teare, ID., 1973. Rapid determination of free proline for water stress studies. Plant Soil. 39: 205207.https://dx.doi.org/10.1007/BF00018060

Bodhankar, S., Grover, M., Hemanth, S., Reddy, G., Rasul, S., Yadav, S.K., Desi, S., Mallappa, M., Mandapaka, M., Srinivasarao, Ch., 2017. Maize seed endophytic bacteria: dominance of antagonistic, lytic enzyme-producing Bacillus spp. 3 Biotech,7(4):232.https://dx.doi.org/10.1007/s13205-017-0860-0

Bodhankar, S., Grover, M., Reddy, G., 2019. In planta screening of maize seed endophytic bacteria for potential applications under dryland conditions. Indian J Dryland Agric. Res. \& Dev. 34(1),53-62.https://dx.doi.org/10.5958/2231 6701.2019.00009.5

Bräutigam, A., Gowik, U., 2010. What can next generation sequencing do for you? Next generation sequencing as a valuable tool in plant research. Plant Biol 12:831-841.https://dx.doi.org/10.1111/j.1438-8677.2010.00373.x.

Byjesh K., Kumar S.N., Aggarwal P.K., 2010. Simulating impacts, potential adaptation and vulnerability of maize to climate change in India. Mitig Adap Strateg Glob Change 15:413-431.https://dx.doi.org/10.1007/s11027-010-9224-3 Choura, M., Brini, F., 2018. Disorder and interactions: What can dehydrins in cereals tell us anymore? Network Biology. 8(4):137-143.

Coutinho, B.G., Licastro, D., Mendonc, a-Previato, L., Cámara, M., Venturi, V., 2015. Plant-influenced gene expression in the rice endophyte Burkholderia kururiensis M130. Molec. Plant-Microbe Interact. 28:10 21.https://dx.doi.org/10.1094/mpmi-07-14-0225-r

Dubois, M., Gilles, K.A., Hamilton, J.K., Rebers, P.A., Smith, F., 1956. Colorimetric methods for determination of sugars of related substances. Ana Chem. 28:350-356.https://dx.doi.org/ 10.1021/ac60111a017

Fukami, J., De La Osa, C., Ollero, F. J., Megías, M., \& Hungria, M. 2018. Coinoculation of maize with Azospirillum brasilense and Rhizobium tropici as a strategy to mitigate salinity stress. Funct Plant Biol. 45(3), 328339.https://dx.doi.org/ 10.1071/fp17167

Gagné-bourque, F., Bertrand, A., Claessens, A., Aliferis, K.A., Jabaji, S., 2016 Alleviation of drought stress and metabolic changes in timothy (Phleum pratense L) colonized with Bacillus subtilis B26. Front Plant Sci. 7:584.https://dx.doi.org/ 10.3389/fpls.2016.00584

Ghosh, D., Sen, S., Mohapatra, S., 2017. Modulation of proline metabolic gene expression in Arabidopsis thaliana under water-stressed conditions by a droughtmitigating Pseudomonas putida strain. Ann Microbiol. 67(10), 655668.https://dx.doi.org/ 10.1007/s13213-017-1294-y

Ghosh, K.G., 2019. Spatial and temporal appraisal of drought jeopardy over the Gangetic West Bengal, eastern India. Geoenviron Disasters. 6,1.https://dx.doi.org/ 10.1186/s40677-018-0117-1

Gond, S.K., Torres, M.S, Bergen, M.S., Helsel, Z., White, J.F. (2015). Induction of salt tolerance and up-regulation of aquaporin genes in tropical corn by rhizobacterium Pantoea agglomerans. Lett. Appl. Microbiol. 60:392399.https://dx.doi.org/ doi:10.1111/lam.12385

Grover M., Madhubala R., Ali S.Z., Yadav S.K., Venkateswarlu B. (2014). Influence of Bacillus spp. strains on seedling growth and physiological parameters of sorghum under moisture stress conditions. J. Basic Microbiol. 54(9):951-961.https://dx.doi.org/ 10.1002/jobm.201300250

Gupta, K., Agarwal, P.K., Reddy, M.K., Jha, B., 2010. SbDREB2A, an A-2 type DREB transcription factor from extreme halophyte Salicornia brachiata confers abiotic stress tolerance in Escherichia coli. Plant Cell Rep. 29(10):1131-7. https://dx.doi.org/ 10.1007/s00299-010-0896-7
Hanin, M., Brini, F., Ebel, C., Toda, Y., Takeda, S. 2011. Plant dehydrins and stress tolerance. Plant Signal Behav. 10:1503-1509.https://dx.doi.org/ doi:10.4161/psb.6.10.17088

Hardoim, P.R., von, Overbeek, L.S., von, Elsas, J.D., 2008. Properties of bacterial endophytes and their proposed role in plant growth. Trends Microbiol 16:463-471.https://dx.doi.org/ 10.1016/j.tim.2008.07.008

Hare, P.D., Cress, W.A., 1997. Metabolic implications of stress induced proline accumulation in plants. Plant Growth Regu. 21:79-102.https://dx.doi.org/ 10.1023/a:1005703923347

Hayano-Kanashiro, C., Calderón-Vázquez, C., Ibarra-Laclette, E., HerreraEstrella, L., Simpson, J., 2009. Analysis of gene expression and physiological responses in three Mexican maize landraces under drought stress and recovery irrigation. PloS One. 4(10):e7531.https://dx.doi.org/ 10.1371/journal.pone.0007531

Hong, S.W., Jon, J.H., Kwak, J.M., Nam, H.G., 1997. Identification of a receptor-like protein kinase gene rapidly induced by abscisic acid, dehydration, high salt, and cold treatments in Arabidopsis thaliana. Plant Physiol. 113(4):1203-1212.https://dx.doi.org/ 10.1104/pp.113.4.1203

Jalota, S.K., Khera, R., Ghuman, B.S., 1998. Method in soil physics. Narosa publishing House, New Delhi. pp: 65- 67. https://dx.doi.org/

Joshi, R., Wani, S.H., Singh, B., Bohra, A., Dar, Z.A., Lone, A.A., Pareek, A., Singla-Pareek, S.L., 2016. Transcription Factors and Plants Response to Drought Stress: Current Understanding and Future Directions. Front Plant Sci. 7:1029.https://dx.doi.org/ 10.3389/fpls.2016.01029

Kamble, M.V., K. Ghosh, M. Rajeevan, and R.P. Samui., 2010. Drought monitoring over India through normalized difference vegetation index (NDVI). Mausam 61: 537-546.

Kavamura, V.N., Santos, S.N., da Silva, J.L., Parma, M.M., Ávila, L.A., Visconti, A., Zucchi, T.D., Taketani R.G., Andreote F.D., de Melo I.S. 2013 Screening of Brazilian cacti rhizobacteria for plant growth promotion under drought. Microbiol. Res. 168:183-191.https://dx.doi.org/ 10.1016 / j.micres.2012.12.002

Li, F.H., Fu, F.L., Sha, L.N., He, L., Li, W.C., 2009. Differential expression of serine/threonine protein phosphatase type-2C under drought stress in maize. Plant Mol. Biol. Rep. 27(1),29. https://dx.doi.org/ 10.1007/s11105-008-0051-6

Li, T., Angeles, O., Radanielson, A., Marcaida, M., Manalo, E., 2015. Drought stress impacts of climate change on rainfed rice in South Asia. Climatic Change.

133:709-720.https://dx.doi.org/ 10.1007/s10584-015-1487-y

Livak, K. J., Schmittgen, T. D., 2001. Analysis of relative gene expression data using real-time quantitative PCR and the 2- $\Delta \Delta C T$ method. Methods, 25(4), $402-$ 408.https://dx.doi.org/ doi:10.1006/meth.2001.1262

Lobell, D.B., Schlenker, W.S., Costa-Roberts, J., 2011. Climate trends and global crop production since 1980. Science. 333:616-620.https://dx.doi.org/ $\underline{10.1126 / \text { science. } 1204531}$

Mancosu, N., Snyder, R., Kyriakakis, G., Spano, D., 2015. Water scarcity and future challenges for food production. Water. 7:975-992.https://dx.doi.org/ 10.3390/w7030975

Meena, K.K., Sorty, A.M., Bitla, U.M., Choudhary, K., Gupta, P., Pareek, A., 2017. Abiotic stress responses and microbe-mediated mitigation in plants: the omics strategies. $\quad$ Front. Plant 8:172.https://dx.doi.org/10.3389/fpls.2017.00172

Naveed, M., Mitter, B., Yousaf, S., 2014. The endophyte Enterobacter sp. FD17: A maize growth enhancer selected based on rigorous testing of plant beneficial traits and colonization characteristics. Biol. Fertil. Soils. 50:249-262 https://dx.doi.org/ 10.1007/s00374-013-0854-y

Okungbowa, F.I., Shittu, H.O., Obiazikwor H.O., 2019. Endophytic bacteria: Hidden protective associates of plants against biotic and abiotic stresses. Not. Sci. Biol.11(2):167-174.https://dx.doi.org/10.15835/nsb11210423

Pandey, V., Ansari, M.W., Tula, S., Yadav, S., Sahoo, R.K., Shukla, N. (2016) Dose-dependent response of Trichoderma harzianum in improving drought tolerance in rice genotypes. Planta. 243:1251-1264.https://dx.doi.org/ 10.1007/s00425-016-2482-x

Prado, C. P. A., Uetanabaro, M., Haddad, C. F. B., 2002. Description of a new reproductive mode in Leptodactylus (Anura, Leptodactylidae), with a review of the reproductive specialization toward terrestriality in the genus. Copeia. 4:1128 1133.https://dx.doi.org/ 8511(2002)002[1128:DOANRM]2.0.CO;2

Sambrook, J., Fritsch, E.F., Maniatis, T., 1989. Molecular cloning. A laboratory manual, $2^{\text {nd }}$ edn. Cold Spring Harbor laboratory, Cold Spring, Harbor, NewYork, 1622.https://dx.doi.org/10.1002/jobm.19840240107

Santana, S.R.A., Voltolini, T.V., Antunes, G.D.R., da Silva VM, Simões, W.L, Morgante, $\frac{1}{\text { C.V. }}$., de $\frac{1}{\text { Freitas, }}$ A.D.S., $\underline{\text { Chaves }}$ A.R.M., Aidar,S.T., Fernandes-Júnior, P.I. 2020. Inoculation of plant growthpromoting bacteria attenuates the negative effects of drought on sorghum. Arch. Microbiol. Jan 13.https://dx.doi.org/10.1007/s00203-020-01810-5.

Sheikh, F.A., Dar, Z.A., Sofi, P.A., Lone, A.A., 2017. Recent Advances in Breeding for Abiotic Stress (Drought) Tolerance in Maize. Int. J. Curr. Microbiol. App. Sci. 6(4): 22262243.https://dx.doi.org/10.20546/ijcmas.2017.604.260 
Shinozaki, K., Yamaguchi-Shinozaki, K., 2007. Gene networks involved in drought stress response and tolerance. J. Exp. Bot. 58:221-227.https://dx.doi.org/ 10.1093/jxb/erl164

Timmusk, S., El-daim, IAA., Copolovici, L., Tanilas, T., Ka, A., Behers, L., Stenstro, E., 2014. Drought-tolerance of wheat improved by rhizosphere bacteria from harsh environments : Enhanced biomass production and reduced emissions of stress volatiles, PLoS ONE 9(5).https://dx.doi.org/ 10.1371/journal.pone.0096086

Timmusk, S., Wagner, EG., 1999. The plant-growth-promoting rhizobacterium Paenibacillus polymyxa induces changes in Arabidopsis thaliana gene expression: a possible connection between biotic and abiotic stress responses. Mol Plant Microbe Interact. 12, 951-959.https://dx.doi.org/ 10.1094/mpmi.1999.12.11.951

Trotel-Aziz, P., Niogret, M.F., Larher, F., 2000. Proline level is partly under the control of abscisic acid in canola leaf discs during recovery from hyper osmotic stress. Physiol. Pl. 110:376-383.https://dx.doi.org/ 10.1111/j.13993054.2000.1100312.x

Vardharajula, S., Ali S. Z., Grover, M., Reddy, G. and Venkateswarlu B. 2011. Drought-tolerant plant growth promoting Bacillus spp.: effect on growth, osmolytes, and antioxidant status of maize under drought stress, Journal of Plant Interactions, 6:1, 1-14.https://dx.doi.org/10.1080/17429145.2010.535178

Waditee, R., Hibino, T., Tanaka, Y., Nakamura, T., Incharoensakdi, A., Hayakawa, S., 2002. Functional characterization of betaine/proline transporters in betaine-accumulating mangrove. J. Biol. Chem. 277:1837818382.https://dx.doi.org/ 10.1074/jbc.m112012200

Xu, J., Yuan, Y., Xu, Y., Zhang, G., Guo, X., Wu, F., Wang, Q., 2014. Identification of candidate genes for drought tolerance by whole-genome resequencing in maize Identification of candidate genes for drought tolerance by whole-genome resequencing in maize. BMC Plant Biol. 14(1),115.https://dx.doi.org/ 10.1186/1471-2229-14-83

Yu, L.X., Setter, T.L., 2003. Comparative transcriptional profiling of placenta and endosperm in developing maize kernels in response to water deficit. Plant Physiol. 131(2):568-582.https://dx.doi.org/ 10.1104/pp.014365

Zaeifizade, M., Goliov, R., 2009. The Effect of the Interaction between Genotypes and Drought Stress on the Superoxide Dismutase and Chlorophyll Content in Durum Wheat Landraces. Turk. J. Boil., 33: 1- 7.https://dx.doi.org/ 10.3906/biy-0801-12

Zlatev, Z. and Yordanov, I. 2004 Effects of soil drought on photosynthesis and chlorophyll fluorescence in common bean plants. Bulgarian Journal of Plant Physiology 30(3-4),3-18. 